\title{
AN INSERVICE TRAINING PROGRAM
}

\section{FOR SANITARIANS IN VIRGINIA}

Adrian L. Carson, Jr., M.D.

$\mathrm{T}$ HE DEVELOPMEN'T of public health services during the past 20 years has automatically carried with it a requirement for personnel able to meet the expressed needs. A higher standard of living and changes in the social structure have been accompanied by a demand for more and better trained personnel to provide those health services required by the public.

The Virginia State Department of Health recognized the situation but, despite much effort, was able to do little on a planned and permanent basis. The recruitment of sanitarians to staff the new jobs became especially difficult in 1950 and 1951. Resignations, 32.7 percent in 1951, often exceeded replacements. Many positions remained vacant for long periods.

Early in 1952, a planned program for inservice training of sanitarians was started. This type of program, tying in training with recruiting, was patterned somewhat along the lines of that used by industry. Salary changes were made. These were important but have never been so great a factor in job stabilization as has been the development of job satisfaction, largely due to the impact of inservice training.

The training program for sanitarians was the first major inservice training activity at-

Dr. Carson before his death was director of local health services and in charge of training activities in the Virginia State Department of Health. The paper was delivered, in much the same form, at the dedication of the Sanitarian Training Center, Orange, Va., on April 15, 1959. tempted within the Virginia State Department of Health. It has since served as a general pattern for additional inservice training programs developed to meet some of the needs of public health nurses, physicians, clerks, and others. Basically, the inservice training of sanitarians consists of :

- Indoctrination for the first month of employment in one of four selected local health departments under the tutelage of an experienced sanitarian who follows an accepted procedure in teaching.

- A 12 weeks' course in the basic fundamentals of sanitation at the Orange Training Center after the sanitarian has had from 3 to 12 months on-the-job supervised experience in his own local health department. The 12 weeks' work in this training facility is a planned combination of didactic teaching supplemented by practical field participation.

- Short refresher courses in special phases of sanitation from time to time as may be indicated. An example is the special training in advanced milk sanitation recently completed by all sanitarians.

The value of training to the individual sanitarian is self-evident. However, a brief appraisal of the program reveals the benefits of inservice training to the health department and to the public, with particular reference to sanitation.

\section{Benefits to the Public}

Inservice training has helped the recruitment of potential sanitarians immensely. The word 
has got around that adequate training will be available to new appointees; consequently, suitable individuals do not hesitate to apply. They feel that they will be given an opportunity to acquire the technical know-how. An excess of applicants gives greater opportunity to pick the ones whom health department officials believe are best adapted to the needs. No longer do we have sanitarian vacancies; we have an excess of good applicants.

The indoctrination period for the first month of employment gives a second opportunity to screen the individual as to how he gets along with people, how he seems to fit into an organization, his capacity for learning, and his general adaptability. During his assignment to the field after the first month of indoctrination, the new sanitarian is closely supervised. $\mathrm{He}$ is not sent to the sanitarian training facility in the Orange County Health Center until and unless we are convinced he is ready for this 12 weeks' course. When the course is completed, the sanitarian is believed to have a good chance for success in his local assignment.

At Orange the sanitarian learns the basic fundamentals of sanitation and is given the advantage of learning not only the "how" of techniques, but also the "why." He learns the importance of staff relationships and how his activity correlates with the work of others on the local health department staff. He learns the practical side of things, as well as the importance of quality of work. He learns the reasons for uniformity of procedure and how to fit into and work with an organization. He learns about local government and is taught that giving the right kind of service for the individual citizen is the fundamental reason for existence of his post.

All of these things are being accomplished- some better than others-but the sum total is a greatly improved service in sanitation. All our budgeted positions are filled, and the type and quality of work being accomplished by our sanitarians place them on a truly professional level.

Of course, there may be occasional local health directors who feel that all this training is not necessary, that they cannot spare their personnel for training, and that perhaps they can get by and not have to have a 12 -week vacancy.

These short interludes can always be handled by borrowing personnel for emergency assignment from within the district or from nearby areas. These difficulties are inconsequential when compared with the rapid turnover and the long-time vacancies that used to exist.

The time spent in inservice training of sanitarians, in the aggregate, is far less than that formerly required to correct "situations" which would not have occurred if the personnel had had a better knowledge of fundamentals.

\section{Conclusion}

A trained and competent group of sanitarians makes for better administration of the presentday programs. Sanitation activities as a whole are becoming much more complicated as technological advances in air pollution, radiation, vending machines, housing, swiming pools, and other areas are being brought to our attention. A well-developed inservice training program makes it possible to focus upon these new problems as they emerge.

Although circumstances forced the Virginia State Department of Health to develop the inservice training program, the values which have accrued are so manifold and so obvious that the department plans to continue and to strengthen the processes whereby these benefits are obtained. 